\title{
A cross sectional study to assess the sFlt- 1:PIGF ratio in pregnant women with and without preeclampsia
}

\author{
Vivek Pant ${ }^{1 *} \mathbb{D}$, Binod Kumar Yadav ${ }^{1}$ and Jyoti Sharma ${ }^{2}$
}

\begin{abstract}
Background: Preeclampsia is a multisystem disorder characterized by vascular endothelial malfunction occurring after 20 weeks of gestation. Placental soluble fms-like tyrosine kinase-1 (sFlt-1) is an antiangiogenic factor and placental growth factor (PIGF) is a potent angiogenic factor. The imbalance between these factors during placenta and fetal development has been shown to play a role in endothelial damage in preeclampsia.

Preeclampsia is the leading cause of maternal mortality in Nepal. This study was designed to compare the sFlt1:PLGF ratio in pregnant women with and without preeclampsia attending Tribhuvan University Teaching Hospital (TUTH).

Method: An observational cross-sectional study was performed in the Gynecology and Obstetrics Department of TUTH involving forty-four subjects with preeclampsia and forty-four age- and gestational-week-matched normal pregnant subjects as controls. Blood pressure, urinary protein levels, serum sFlt-1 levels, serum PIGF levels and the sFlt-1:PIGF ratio was compared in both the cases and control. The concentrations of sFlt-1 and PIGF were measured with commercially available ELISA kits. SPSS ver. 20.0 was used to analyze the data.
\end{abstract}

Results: There was no significant difference in age or gestational age in either study group. The ratio of the sFlt-1 and PIGF concentrations was significantly higher in women with preeclampsia (31.6 \pm 9.6$)$ than in the controls (3.2 \pm 1.3$)$. Likewise, diastolic blood pressure was significantly associated ( $p$-value 0.000 ), whereas the severity of proteinuria was not associated ( $p$-value 0.773 ) with the sFlt-1:PIGF ratio in women with preeclampsia. The significantly higher ratio (35.51 \pm 8.1 versus $25.4 \pm 8.7$ ) was found in women with preeclampsia who developed complications than the group of women with preeclampsia who did not develop complication.

Conclusion: The sFIt-1:PIGF ratio is significantly higher in Nepalese women with preeclampsia than in normal controls and this finding can be applied for further planned clinical trials.

Keywords: Preeclampsia, Soluble fms-like tyrosine kinase - 1 (sFlt-1), Placental growth factor (PIGF), Nepal

\section{Background}

Preeclampsia is a multisystem disorder characterized by the new onset of hypertension (above $140 / 90 \mathrm{mmHg}$ ) and proteinuria ( $0.3 \mathrm{~g}$ in a $24 \mathrm{~h}$ urine sample) occurring after 20 weeks of gestation [1]. Preeclampsia is associated with significant morbidity and mortality in both the mother and fetus. The maternal complications that can occur during pregnancy are oliguric renal failure, oligohydramnios, placental disruption, eclampsia, HELLP (Hemolysis, elevated

\footnotetext{
*Correspondence: drvpant@gmail.com

'Department of Clinical Biochemistry, Institute of Medicine, Tribhuvan

University Teaching Hospital, Kathmandu, Nepal

Full list of author information is available at the end of the article
}

liver enzyme and low platelet syndrome) and preterm labour [1]. Similarly, postpartum hemorrhage and puerperal sepsis can occur as complications after labour [1,2]. Complications in the fetus and neonate are related to severity and duration of preeclampsia and include prematurity, fetal growth restriction, intrauterine fetal death and asphyxia [3]. Maternal symptoms of preeclampsia subside after delivery.

The underlying pathophysiology of preeclampsia involves endothelial dysfunction and vasospasm originating primarily in the placenta [4]. The abnormal development of blood vessels in placenta results in its under perfusion. This relative hypoxic condition in placenta causes release of antiangiogenic factors into the maternal blood

C The Author(s). 2019 Open Access This article is distributed under the terms of the Creative Commons Attribution 4.0 International License (http://creativecommons.org/licenses/by/4.0/), which permits unrestricted use, distribution, and 
circulation which leads to the alteration of maternal systemic endothelial function and causes hypertension [5].

Placental growth factor (PIGF), a glycoprotein that regulates blood vessel development is a member of vascular endothelial growth factor (VEGF) family [6]. VEGF interacts with their tyrosine kinase receptors which are of three types [7]. PIGF propagates signals through VEGF Receptor1 (VEGF-R1) or Flt-1(fms like tyrosine kinase-1) but cannot bind VEGF Receptor - 2 (VEGF-R2) [6]. VEGF itself propagates signals through VEGF Receptor-2 (VEGF-R2) though it can bind to other receptors [6, 8]. PIGF enhances the activity of VEGF by competitively binding to VEGF-R1 and thus increasing VEGF interaction with VEGF R2, which is a potent stimulus for angiogenesis $[6,8]$.

The soluble variant of VEGF receptor-1 is also known as soluble fms like tyrosine kinase-1(sFlt-1), is an alternatively spliced variant of VEGF R1 which is induced by placental ischemia [9]. sFlt-1 inhibits angiogenesis by reducing free circulating levels of VEGF and PIGF [8]. This reduction of these pro angiogenic factors by sFlt-1 is brought by binding them in the circulation and preventing their interaction with receptors $[8,10]$. VEGF receptor family shares the common feature of having extracellular domain consisting of seven immunoglobulins like domain and contains transmembrane and intracellular signaling domain [11]. As sFlt1 is the spliced variant, it lacks the transmembrane and intracellular signaling domains [12]. This leads to free secretion of this anti angiogenic factor into the maternal circulation thus inhibiting the beneficial effects of proangiogenic factors on maternal endothelium [13].

The major share of maternal and perinatal morbidity and mortality in developing nation like Nepal can be attributed to preeclampsia/Eclampsia [14]. In clinical practice, the routine screening for preeclampsia is done by measuring blood pressure and quantification of protein in the urine. There is currently no standard practice for laboratory testing in early pregnancy that can predict the occurrence of preeclampsia. Rather, various preventive options are available for the high risk group such as administration of aspirin or calcium supplementation [15]. There is a need of sensitive laboratory test for screening preeclampsia because relying only on blood pressure measurement and proteinuria detection can be misleading. The main objective of the present study is to compare the serum sFlt-1:PlGF ratio in pregnant Nepalese women with and without preeclampsia; this ratio is also currently being tested in other parts of the world.

\section{Methods}

An observational cross-sectional study was performed for a period of one year from August 2016 to August 2017. Singleton pregnant women $\geq 20$ years of age with weeks of gestation ranging from 20 until delivery presenting with features of preeclampsia and the absence of exclusion criteria were recruited for this study by purposive sampling. The exclusion criteria were advanced maternal age ( $>35$ years, who might have essential hypertension), multiple fetuses, a history of chronic hypertension, a fetus with a congenital malformation incompatible with life as evidenced by ultrasonography (USG), the presence of disease causing proteinuria other than preeclampsia and placental insufficiency. Cases of preeclampsia in which the symptoms had started before 34 weeks of gestation were grouped as cases of earlyonset preeclampsia. Similarly, cases of preeclampsia in which the symptoms had started after 34 weeks were grouped as cases of late-onset preeclampsia. Cases of preeclampsia were divided into mild and severe cases as defined by the American College of Obstetricians and Gynecologists 2012-2013 [1]. Forty-four age- and period-of-gestation (POG)-matched normal pregnant women served as controls; these were women attending regular antenatal visits in the Gynecology and Obstetrics OPD. Sample size was calculated by obtaining the prevalence of preeclampsia in the Gynecology and Obstetrics Department of our institute. Written consent was obtained from each participant.

The patients' medical records were reviewed for the findings of USG, urinary protein level and blood pressure at the time of presentation. Five milliliters of venous blood was collected and centrifuged within $30 \mathrm{~min}$; the serum was stored at $-40^{\circ} \mathrm{C}$ until the analysis of serum sFlt- 1 and PIGF. The sFlt- 1 and PIGF levels of all samples were determined in a single run according to the manufacturer's instructions for the research solid phase enzyme-linked immunosorbent assay (ELISA) kits purchased from Reddot Biotech Inc., Canada. The intra-assay coefficients of variation were $8.1 \%$ for serum sFlt- 1 and $6.4 \%$ for PIGF.

Data were analyzed using SPSS for Windows version 20.0. All values are expressed as the mean $+/$ - standard deviation. Data were tested for normality of distribution, and data that were not normally distributed were analyzed with nonparametric tests. Intergroup comparisons of continuous data were performed with Student's $t$ test or the Mann-Whitney U-test where appropriate. The serum sFlt1:PIGF ratio is not increased in patients with preeclampsia was the hypothesis tested. Ethics approval was obtained from the Institutional Review Board (IRB) of the Institute of Medicine [Reference number - 263(6-11-E) $)^{2}$ 073/074].

\section{Results}

The clinical details of the participants are shown in Table 1 . Eighteen $(40 \%)$ women with preeclampsia had early onset ( $<34$ weeks), and twenty-six (60\%) women with preeclampsia had late onset (>34 weeks). Twenty-three (52.27\%) cases of preeclampsia were mild, and twenty-one (47.72\%) cases were severe. 
Table 1 Clinical details of participants.

\begin{tabular}{lll}
\hline Clinical details of participants & $\begin{array}{l}\text { Preeclampsia } \\
(N=44)\end{array}$ & $\begin{array}{l}\text { Normal pregnancy } \\
(N=44)\end{array}$ \\
\hline Age (Mean \pm SD) years & $27.3 \pm 3.1$ & $26.28 \pm 2.5$ \\
$\begin{array}{l}\text { Period of gestation } \\
\text { (Mean } \pm \text { SD) weeks }\end{array}$ & $35.1 \pm 3.0$ & $34.9 \pm 3.2$ \\
Parity & $21(47.72 \%)$ & $15(34.09 \%)$ \\
& multiparous & multiparous \\
& $23(52.27 \%)$ & $29(65.90 \%)$ \\
& primiparous & primiparous \\
\hline
\end{tabular}

There was a significant difference in the mean values of DBP, sFlt-1, and PlGF and the sFlt-1:PlGF ratio between the cases and controls, as shown in Table 2 and Figs. 1, 2, 3, 4. Comparisons of the levels of sFlt-1 and PIGF and their ratio in mild vs. severe cases and early onset vs. late onset preeclampsia are shown in Table 3.

The numbers of patients with trace, $1+, 2+, 3+$, and $4+$ proteinuria were seven (7.9\%), fourteen (15.7\%), ten $(11.2 \%)$, ten $(11.2 \%)$ and three (3.4\%), respectively. There was no significant association found ( $P$ value 0.773 ) between the degree of proteinuria and the ratio of sFlt-1:PlGF in patients with preeclampsia.

Patients with preeclampsia were divided into two groups based on the presence or absence of complications. When the mean sFlt-1:PlGF ratio was compared between these groups, a significantly higher ratio $(35.51 \pm 8.1$ versus $25.4 \pm 8.7$ ) was found in the group with complications. (Fig. 5) The types of complications and their frequencies in patients with preeclampsia are shown in Table 4.

\section{Discussion}

The relative overproduction of sFlt-1 than VEGF by placental tissue in preeclampsia is responsible for various clinical manifestations seen in preeclampsia [16]. Studies have shown that this spliced variant decreases PIGF and contributes to endothelial dysfunction, hypertension, and proteinuria observed in women with preeclampsia

Table 2 Comparison of means of age, POG, sFlt-1, PIGF and sFlt-1:PIGF ratio in case and control

\begin{tabular}{llll}
\hline Parameters & Preeclampsia Mean \pm SD & Normal Mean \pm SD & $P$-value \\
\hline Age & $27.3 \pm 3.1$ & $26.3 \pm 2.5$ & 0.393 \\
POG & $35.3 \pm 3.0$ & $34.9 \pm 3.2$ & 0.875 \\
SFIt-1 & $2575.50 \pm 775.03$ & $453.75 \pm 156.24$ & $<0.001^{*}$ \\
PIGF & $86.31 \pm 26.9$ & $155.8 \pm 63.89$ & $<0.001^{*}$ \\
Ratio & $31.6 \pm 9.6$ & $3.2 \pm 1.3$ & $<0.001^{*}$ \\
DBP & $101.1 \pm 9.4$ & $76.3 \pm 5.6$ & $<0.001^{*}$
\end{tabular}

Abbreviation: POG- period of gestation, DBP- Diastolic blood pressure, sFlt-1 soluble Fms like tyrosine kinase-1, PIGF- Placental growth factor

* significant at $<0.001$
$[13,17]$. To the best of our knowledge, this is the first study in Nepal comparing the levels of sFlt-1 and PlGF in pregnant women with and without preeclampsia.

In our study, the serum PlGF level was decreased ( $86 \pm$ $26.9 \mathrm{pg} / \mathrm{ml}$ versus $155 \pm 63.89 \mathrm{pg} / \mathrm{ml}$ ) and the serum sFlt- 1 level was elevated $(2575 \pm 775.03 \mathrm{pg} / \mathrm{ml}$ versus $453 \pm$ $156.24 \mathrm{pg} / \mathrm{ml}$ ) in the pregnant women with preeclampsia than the pregnant women without preeclampsia. Similarly, the ratio of sFlt-1/PIGF in the pregnant women with preeclampsia was significantly higher than that in the control group. In a study by Levine et al., a higher mean sFlt-1 value of $4382 \mathrm{pg} / \mathrm{ml}$ was reported in women with preeclampsia compared to value of $1643 \mathrm{pg} / \mathrm{ml}$ in the control group [18]. In the two separate studies by Kim et al. [19] and Gurnadi JI et al. [20], elevated serum concentrations of sFlt-1 in women with preeclampsia was found.

In our study, the serum sFlt-1 concentration was significantly higher in women with severe preeclampsia than in those with mild preeclampsia $(p<0.001)$. It has been found that the elevation of the sFlt- 1 concentration reduces the PIGF concentration in severe preeclampsia, and this occurs before the onset of clinical symptoms [21, 22]. Chaiworapongsa et al., reported that the increasing concentration of sFlt-1 correlates with severity of disease [23]. Similarly, the severity of preeclampsia is also found positively correlated with the increased urinary output of sFlt- 1 at the time of clinical manifestation [24]. These findings suggest that periodic monitoring of sFlt-1 levels in cases of preeclampsia can be important in the early identification of the onset of severity of preeclampsia.

In the present study, the degree of proteinuria was not significantly associated with the ratio of sFlt-1:PlGF in women with preeclampsia ( $p$-value 0.773 ). In this study, a significant number of women with preeclampsia were the hospitalized patients to whom antihypertensive drugs and intravenous fluids were already administered. This might have reduced the severity of proteinuria in these patients, which may explain the insignificant association of proteinuria with the ratio of sFlt-1:PlGF. Proteinuria was estimated by the dipstick method in our study, which is a more qualitative measure. The $24-\mathrm{h}$ protein or urine/protein creatinine ratio is more reliable, but it could not be performed in our patients. Most patients in this study had already manifested preeclamptic symptoms. Proteinuria was present in all patients with preeclampsia, and the degree of proteinuria was higher in severe than mild cases of preeclampsia. This finding is similar to the findings of Barton et al., who reported that proteinuria generally increase as preeclampsia progressed but that increased urinary protein excretion may be a late finding [25]. In a recently published study by Dong et al., the severity of preeclampsia was higher when proteinuria was above 0.3 $\mathrm{g} / \mathrm{L}[26]$. 


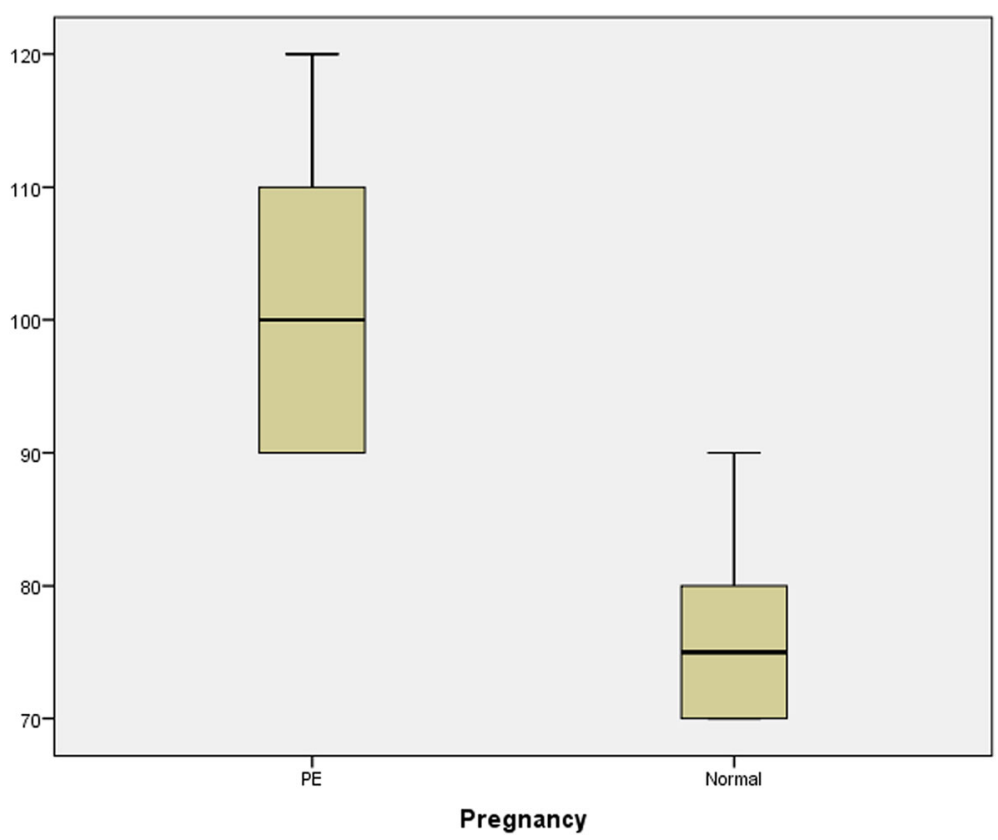

Fig. 1 Box plot showing mean value of diastolic blood pressure in case and control

In our study, the diastolic blood pressure was significantly associated with the sFlt-1:PlGF ratio in the group with preeclampsia. This finding is consistent with those of previous studies. Reiss et al. found that both the systolic and diastolic blood pressure values were significantly higher in the first trimester for women who later developed preeclampsia than for those who did not [27]. Various theories have been put forward regarding the etiology of hypertension in preeclampsia. It has been suggested that the circulating sFlt-1 concentration in preeclamptic patients antagonizes physiologic dilatation of blood vessels, thus contributing to hypertension [13]. The current medical practice for diagnosing preeclampsia, which is also a simple and inexpensive method of screening in low-resource settings such as ours, is the measurement of blood

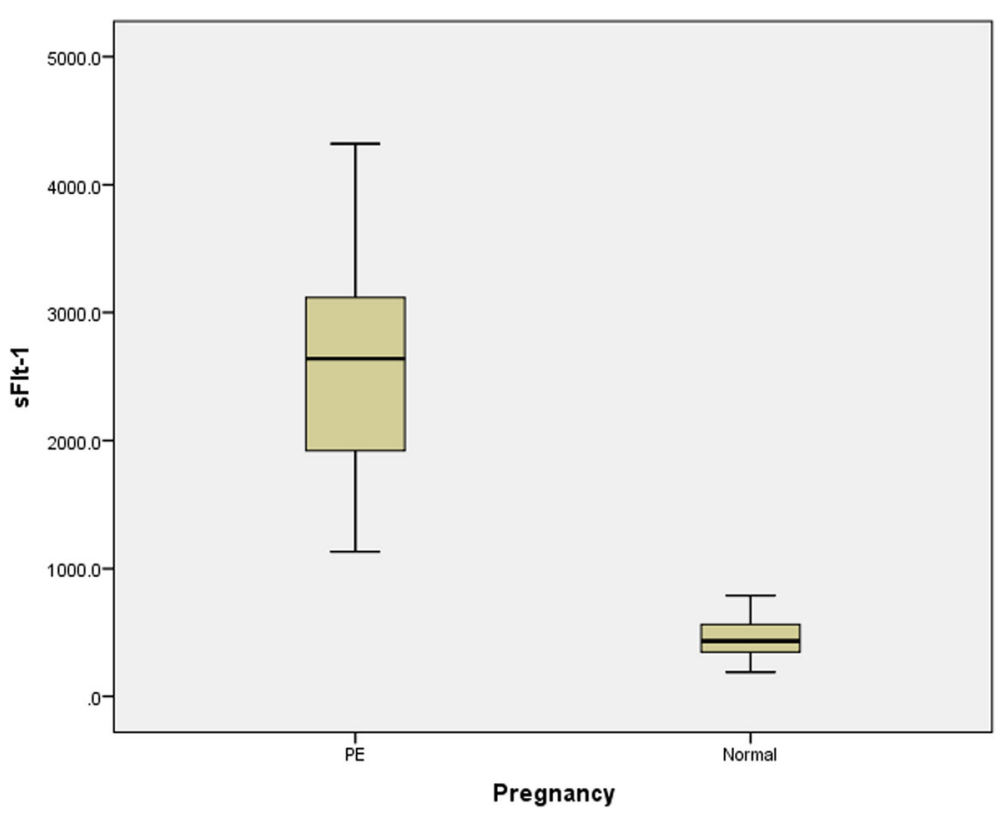

Fig. 2 Box plot showing mean value of sFlt-1 in case and control 


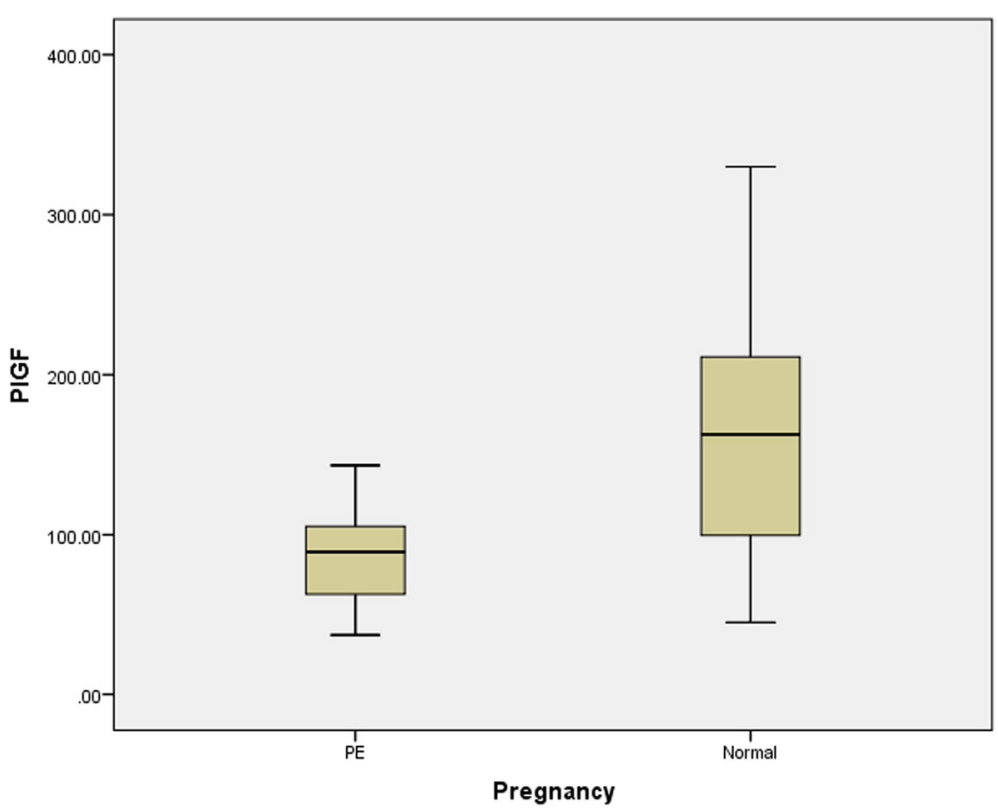

Fig. 3 Box plot showing mean value of PIGF in case and control

pressure and proteinuria. While the most recent diagnostic markers, such as the sFlt-1:PlGF ratio, are currently used in other parts of the world, we are still lagging behind in the application of routine screening tests. The recent trends in Nepal showed an increased use of antenatal care; however, $17 \%$ of pregnant women receive no antenatal care (ANC), and among those who do, routine screening is often not carried out [28]. Thus, the findings of this study emphasize the importance of measuring blood pressure.

In the present study, the concentrations of sFlt-1 and PIGF were significant higher in patients with early-onset preeclampsia $(<34$ weeks $)$ than in those with late-onset PE (>34 weeks). A similar finding was reported in a study by Chaiworapongsa et al., in which the sFlt-1 concentrations were higher in

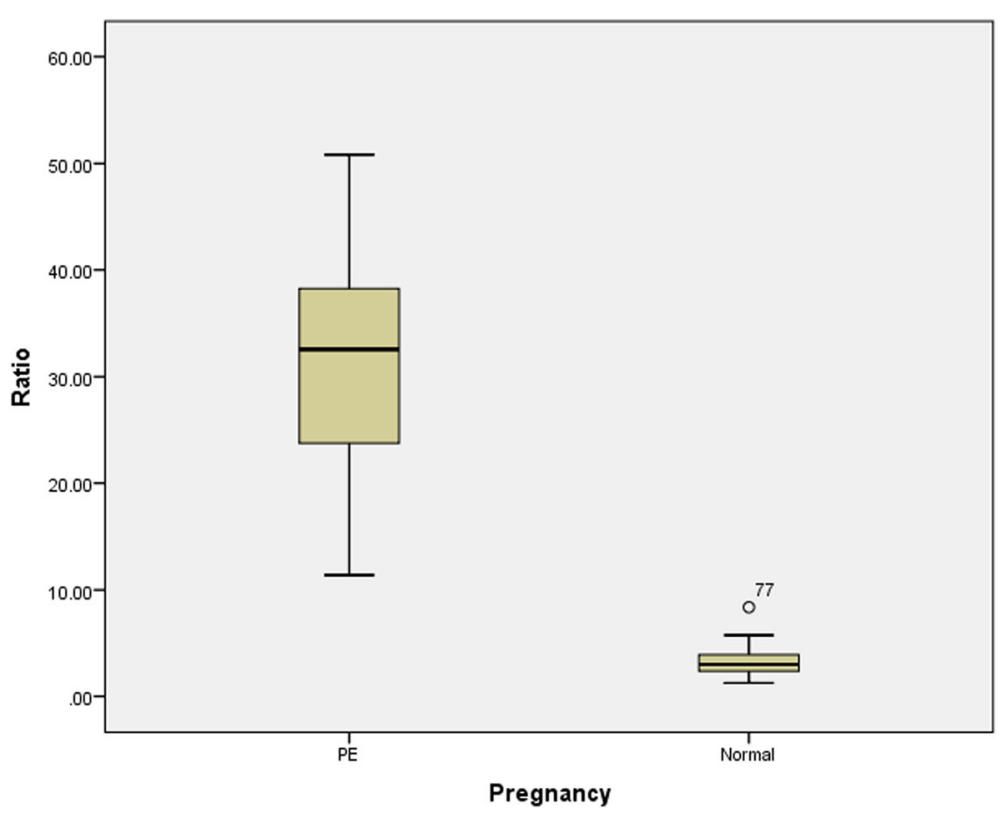

Fig. 4 Box plot showing mean ratio of sFlt-1: PIGF in case and control 
Table 3 Comparison of sFlt-1, PIGF and ratio in mild/severe and early/late onset PE

\begin{tabular}{llll}
\hline Preeclampsia & sFlt-1 (mean) & PIGF (mean) & Ratio (mean) \\
\hline Severe PE & 2885.16 & 92.56 & 31.51 \\
Mild PE & 2292.76 & 80.60 & 31.72 \\
P-value & $0.010^{*}$ & 0.143 & 0.945 \\
Early onset & 3017.11 & 95.24 & 32.79 \\
Late onset & 2269.76 & 80.12 & 30.81 \\
P-value & $0.001^{*}$ & $0.050^{*}$ & 0.945 \\
\hline
\end{tabular}

* significant at 0.05

women with early-onset ( $<34$ weeks) preeclampsia [23]. Wikström et al. reported that women with earlyonset PE had 43 times higher median plasma sFlt-1 levels and 21 times lower median plasma PIGF levels than controls $(p<0.001)$ [29]. It has been found that late onset preeclampsia is more prevalent than early onset preeclampsia [30]. The lower concentrations of sFlt-1 and PlGF in late-onset preeclampsia are likely due to its non-placental origin because it occurs due to pre-existing maternal endothelial dysfunction [31].

This is the first study in the Nepalese population reporting increased sFlt1:PIGF ratio in women with preeclampsia than in normal controls. Despite being the leading cause of high maternal mortality rate in Nepal, the clinical study in preeclampsia is limited. Various prospective clinical studies could be done in pregnant women in Nepal based on findings of our study. For example, Ziesler et al. in their study suggested that the sFlt-1:PIGF ratio may be useful as a negative predictive test in clinically suspected cases [32]. Our finding is important for future clinical studies in
Table 4 Types of complication and its frequency in cases of preeclampsia

\begin{tabular}{lll}
\hline Complication & Frequency & Percentage \\
\hline Abruptio Placentae & 1 & $2.27 \%$ \\
Birth Asphyxia & 1 & $2.27 \%$ \\
Persistent thrombocytopenia & 1 & $2.27 \%$ \\
IUFD & 1 & $2.27 \%$ \\
Elevated Liver enzymes & 2 & $4.54 \%$ \\
Eclampsia & 4 & $9.09 \%$ \\
IUGR & 8 & $18.18 \%$ \\
Low birth weight & 9 & $20.45 \%$ \\
\hline
\end{tabular}

suspected cases of preeclampsia. It is also worth correlating these markers with complications of preeclampsia in mother and fetus.

The limitation of our study is that the samples were taken from confirmed cases of preeclampsia at one point of time rather than the prospective study in the suspected cases of preeclampsia. The next limitation was the use of the dipstick method for determination of proteinuria and the use of research ELISA kits, which are less sensitive.

\section{Conclusion}

In this study, the sFlt-1 level was increased and the PIGF level was decreased in Nepalese women with preeclampsia compared to normal pregnant women. Similarly, the ratio of sFlt-1:PlGF was higher in women with preeclampsia than those without preeclampsia.

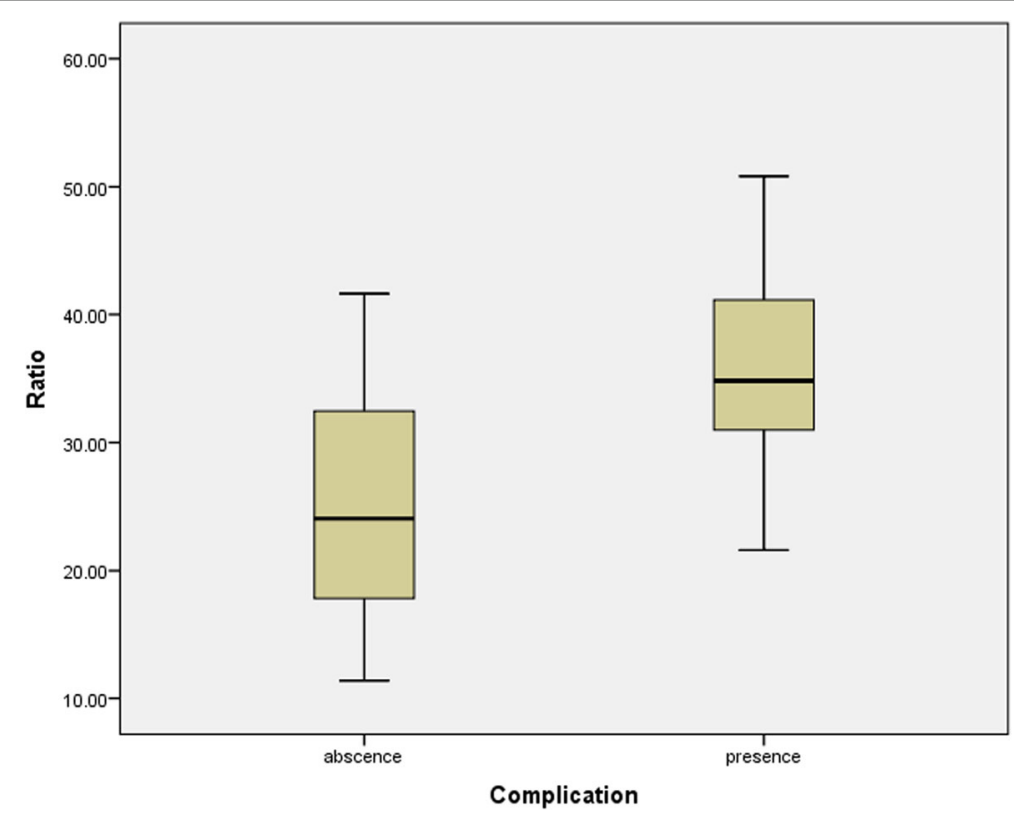

Fig. 5 Box plot showing mean ratio of sFlt-1: PIGF in preeclampsia cases with absence or presence of complication 
The results of our study will be helpful for further planned trials in clinically suspected cases of preeclampsia in Nepal.

\section{Abbreviations}

ACOG: American College of Obstetricians and Gynecologists; ANC: Antenatal Care; DBP: Diastolic Blood pressure; E: Eclampsia; ELISA: Enzyme Linked Immunosorbent Assay; HELLP: Hemolysis Elevated Liver enzyme and low platelet; IOM: Institute of Medicine; IRB: Institutional research board; OPD: Out patient department; PE: Preeclampsia; PIGF: Placental Growth Factor; POG: Period of Gestation; sFlt-1: Soluble fms like tyrosine kinase-1; SPSS: Statistical package for social science; TUTH: Tribhuvan university teaching hospital; USG: Ultrasonography

\section{Acknowledgements}

Authors would like to acknowledge Dr. Arjun Tumbapo, Dr. Shaila RL Rana, Dr. Sarmila Prajapati and Mr. Binod Aryal for their continuous support throughout this study. The authors would also like to thank the University Grant Commission, Nepal, for providing grants supporting this study. The part of this study was accepted for poster presentation in 23rd IFCC-EFLM European Congress of Clinical Chemistry and Laboratory Medicine [33].

\section{Authors' contributions}

BKY and JS designed the study. VP collected data, performed laboratory test, analyzed the data and has written this manuscript. JS approved the final version. All authors read and approved the final manuscript.

\section{Funding}

The study was funded by the University Grants Commission of Nepal.

\section{Availability of data and materials}

The data that support the findings of this study are available from the Institutional Research Board of the Institute of Medicine, but restrictions apply to the availability of these data, which were used under license for the current study and so are not publicly available. Data are, however, available from the authors upon reasonable request and with permission of the Institutional Research Board of the Institute of Medicine.

\section{Ethics approval and consent to participate}

Ethics approval to conduct this study was obtained from the Institutional Research Board of the Institute of Medicine. The reference number is 263(6$11-E)^{2}$ 073/074. Written consent was obtained from each participant.

\section{Consent for publication}

Not applicable.

\section{Competing interests}

The authors declare that they have no competing interests.

\section{Author details}

${ }^{1}$ Department of Clinical Biochemistry, Institute of Medicine, Tribhuvan University Teaching Hospital, Kathmandu, Nepal. ${ }^{2}$ Department of Gynecology and Obstetrics, Institute of Medicine, Tribhuvan University Teaching Hospital, Kathmandu, Nepal.

\section{Received: 23 May 2018 Accepted: 4 July 2019}

Published online: 25 July 2019

\section{References}

1. American College of Obstetricians and Gynecologists. Hypertension in pregnancy. Report of the American College of Obstetricians and Gynecologists' task force on hypertension in pregnancy. Obstetrics and gynecology. 2013 Nov;122(5):1122.

2. Matthys LA, Coppage KH, Lambers DS, Barton JR, Sibai BM. Delayed postpartum preeclampsia: an experience of 151 cases. Am J Obstet Gynecol. 2004 May 1:190(5):1464-6.

3. Saadat M, Nejad SM, Habibi G, Sheikhvatan M. Maternal and neonatal outcomes in women with preeclampsia. Taiwanese Journal of Obstetrics and Gynecology. 2007 Sep 1;46(3):255-9.
4. LaMarca B. Endothelial dysfunction; an important mediator in the pathophysiology of hypertension during preeclampsia. Minerva Ginecol. 2012 Aug;64(4):309.

5. Cunningham FG, Leveno KJ, Bloom SL, Hauth JC, Rouse DJ, Spong CY. Pregnancy hypertension. Williams's obstetrics. 2010;23:706.

6. Ferrara N, Gerber HP, LeCouter J. The biology of VEGF and its receptors. Nat Med. 2003 Jun;9(6):669.

7. Roskoski R Jr. VEGF receptor protein-tyrosine kinases: structure and regulation. Biochem Biophys Res Commun. 2008 Oct 24;375(3):287-91.

8. Keyt BA, Nguyen HV, Berleau LT, Duarte CM, Park J, Chen H, Ferrara N. Identification of vascular endothelial growth factor determinants for binding KDR and FLT-1 receptors generation of receptor-selective VEGF variants by site-directed mutagenesis. J Biol Chem. 1996 Mar 8;271(10):5638-46.

9. Robinson CJ, Stringer SE. The splice variants of vascular endothelial growth factor (VEGF) and their receptors. J Cell Sci. 2001 Mar 1;114(5):853-65.

10. Waltenberger J, Claesson-Welsh L, Siegbahn A, Shibuya M, Heldin CH. Different signal transduction properties of KDR and Flt1, two receptors for vascular endothelial growth factor. J Biol Chem. 1994 Oct 28;269(43):26988-95.

11. Heldin CH. Dimerization of cell surface receptors in signal transduction. Cell. 1995 Jan 27;80(2):213-23.

12. Wathén KA, Tuutti $E$, Stenman UH, Alfthan $H$, Halmesmäki E, Finne $P$, Ylikorkala O, Vuorela P. Maternal serum-soluble vascular endothelial growth factor receptor-1 in early pregnancy ending in preeclampsia or intrauterine growth retardation. J. Clin. Endocrinol. Metabol. 2006 Jan 1;91(1):180-4.

13. Maynard SE, Min JY, Merchan J, Lim KH, Li J, Mondal S, Libermann TA, Morgan JP, Sellke FW, Stillman IE, Epstein FH. Excess placental soluble fmslike tyrosine kinase 1 (sFlt1) may contribute to endothelial dysfunction, hypertension, and proteinuria in preeclampsia. J Clin Invest. 2003 Mar 1; 111(5):649-58.

14. Ghimire S. Eclampsia: Feto-maternal outcomes in a tertiary Care Centre in Eastern Nepal. J Nepal Med Assoc. 2016 Jan;1:54(201).

15. Thangaratinam S, Langenveld J, Mol BW, Khan KS. Prediction and primary prevention of pre-eclampsia. Best Pract. Res Clin Obstet \& Gynaecol. 2011 Aug 1;25(4):419-33.

16. Tsatsaris V, Goffin F, Munaut C, Brichant JF, Pignon MR, Noel A, Schaaps JP, Cabrol D, Frankenne F, Foidart JM. Overexpression of the soluble vascular endothelial growth factor receptor in preeclamptic patients: pathophysiological consequences. J. Clin. Endocrinol. Metabol. 2003 Nov 1; 88(11):5555-63.

17. De Vivo A, Baviera G, Giordano D, Todarello G, Corrado F, D'anna R. Endoglin, PIGF and sFlt-1 as markers for predicting pre-eclampsia. Acta Obstet Gynecol Scand. 2008 Aug;87(8):837-42.

18. Levine RJ, Lam C, Qian C, Yu KF, Maynard SE, Sachs BP, Sibai BM, Epstein FH, Romero R, Thadhani R, Karumanchi SA. Soluble endoglin and other circulating antiangiogenic factors in preeclampsia. N Engl J Med. 2006 Sep 7;355(10):992-1005.

19. Kim SY, Ryu HM, Yang JH, Kim MY, Han JY, Kim JO, Chung JH, Park SY, Lee MH, Kim DJ. Increased SFIt-1 to PIGF ratio in women who subsequently develop preeclampsia. J Korean Med Sci. 2007 Oct 1;22(5):873-7.

20. Gurnadi Jl, Mose J, Handono B, Satari MH, Anwar AD, Fauziah PN, Pramatirta AY, Rihibiha DD. Difference of concentration of placental soluble fms-like tyrosine kinase-1 (sFlt-1), placental growth factor (PIGF), and sFIt-1/PIGF ratio in severe preeclampsia and normal pregnancy. BMC research notes. 2015 Dec;8(1):534.

21. Lam C, Lim K-H, Karumanchi SA. Circulating angiogenic factors in the pathogenesis and prediction of preeclampsia. Hypertension. 2005;46(5):1077-85.

22. Stepan H, Geide A, Faber R. Soluble fms-like tyrosine kinase 1. N Engl J Med 2004 Nov 18:351(21):2241-2.

23. Chaiworapongsa T, Romero R, Espinoza J, Bujold E, Kim YM, Gonçalves LF, Gomez R, Edwin S. Evidence supporting a role for blockade of the vascular endothelial growth factor system in the pathophysiology of preeclampsia: young investigator award. Am. J Obstet. Gynecol. 2004 Jun 1;190(6):1541-7.

24. Buhimschi CS, Norwitz ER, Funai E, Richman S, Guller S, Lockwood CJ, Buhimschi IA. Urinary angiogenic factors cluster hypertensive disorders and identify women with severe preeclampsia. Am. J. Obstet. Gynecol. 2005 Mar 1;192(3):734-41.

25. Barton JR, O'Brien JM, Bergauer NK, Jacques DL, Sibai BM. Mild gestational hypertension remote from term: progression and outcome. Am. J. Obstet. Gynecol. 2001 Apr 1;184(5):979-83.

26. Dong X, Gou W, Li C, Wu M, Han Z, Li X, Chen Q. Proteinuria in preeclampsia: not essential to diagnosis but related to disease severity and 
fetal outcomes. Pregnancy Hypertension: An International Journal of Women's Cardiovascular Health. 2017 Apr 1;8:60-4.

27. Reiss RE, O'Shaughnessy RW, Quilligan TJ, Zuspan FP. Retrospective comparison of blood pressure course during preeclamptic and matched control pregnancies. Am. J. Obstet. Gynecol. 1987 Apr 1;156(4):894-8.

28. Kearns AD, Caglia JM, Hoope-Bender P, Langer A. Antenatal and postnatal care: a review of innovative models for improving availability, accessibility, acceptability and quality of services in low-resource settings. BJOG Int J Obstet Gynaecol. 2016 Mar 1;123(4):540-8.

29. Wikström AK, Larsson A, Eriksson UJ, Nash P, Nordén-Lindeberg S, Olovsson M. Placental growth factor and soluble FMS-like tyrosine kinase-1 in early-onset and late-onset preeclampsia. Obstet Gynecol. 2007 Jun 1;109(6):1368-74.

30. Lisonkova S, Joseph KS. Incidence of preeclampsia: risk factors and outcomes associated with early-versus late-onset disease. Am J Obstet Gynecol. 2013 Dec 1;209(6):544-e1.

31. Ferrazzi E, Stampalija T, Aupont JE. The evidence for late-onset preeclampsia as a maternogenic disease of pregnancy. Fetal and Maternal Medicine Review. 2013 Feb;24(1):18-31.

32. Zeisler H, Llurba E, Chantraine F, Vatish M, Staff AC, Sennström M, Olovsson M, Brennecke SP, Stepan H, Allegranza D, Dilba P. Predictive value of the sFlt-1: PIGF ratio in women with suspected preeclampsia. N Engl I Med. 2016 Jan 7:374(1):13-22

33. https://doi.org/10.1016/j.cca.2019.03.540

\section{Publisher's Note}

Springer Nature remains neutral with regard to jurisdictional claims in published maps and institutional affiliations.

Ready to submit your research? Choose BMC and benefit from:

- fast, convenient online submission

- thorough peer review by experienced researchers in your field

- rapid publication on acceptance

- support for research data, including large and complex data types

- gold Open Access which fosters wider collaboration and increased citations

- maximum visibility for your research: over $100 \mathrm{M}$ website views per year

At BMC, research is always in progress.

Learn more biomedcentral.com/submissions 